\title{
БІОХІМІЧНІ МАРКЕРИ МОРФОЛОГІЧНИХ ЗМІН У МІОКАРДІ ЩУРІВ ПРИ ЙОГО АДРЕНАЛІНОВО-КАЛЬЦІЄВОМУ УШКОДЖЕННІ
}

Вступ. Інфраркт міокарда є динамічним процесом, що супроводжується переходом оборотних змін до необоротного ішемічного ушкодження і завершується заміною зменшеної частини міокарда фріброзним рубцем.

Мета дослідження - визначити взаємозв'язок між змінами продуктів пероксидного окиснення ліпідів, окисної модифрікації білків (ОМБ), нітрит-аніона та морфологічними порушеннями в серці тварин з адреналіново-кальцієвою моделлю його ушкодження і при корекції патологічного процесу кверцетином.

Методи дослідження. Досліди виконано на 195 щурах-самцях лінії Вістар віком 5-6 місяців. Тваринам вводили адреналіну гідротартрат і глюконат кальцію, для корекції - кверцетин. У серці визначали концентрацію дієнових кон'югатів, ТБК-активних продуктів, ОМБ, нітрит-аніона. Гістологічні препарати вивчали при забарвленні гематоксиліном і еозином, за Гейденгайном, а також розглядали їх у поляризованому світлі.

Результати й обговорення. При адреналіново-кальцієвій моделі ушкодження серця найбільше зростання концентрації дієнових кон'югатів і ТБК-активних продуктів спостерігали через 7 та 14 діб, ОМБ - через 24 год, через 3 доби (максимум), через 7 діб. Концентрація нітрит-аніона була високою в проміжку від 24 год до 21 доби (через з і 14 діб відмічено максимуми). Кверцетин сприяв зменшенню вмісту продуктів ОМБ через 7, 14 і 28 діб, дієнових кон'югатів - через 7, 14 і 21 доби, ТБК-активних продуктів, нітрит-аніона - в усі терміни дослідження. При морфологічному дослідженні виявлено порушення тинкторіальних властивостей, виникнення некрозів, контрактур. Зміни наростали зі збільшенням терміну дослідження та відповідали за часом відхиленням біохімічних показників. Кверцетин попереджував виникнення ушкоджень.

Висновки. Виявлені морфологічні зміни підтверджували дані біохімічних показників. Морфологічні зміни наростали зі збільшенням терміну дослідження та відповідали відхиленням біохімічних показників. Кверцетин зменшував виникнення ушкоджень серця.

КЛЮчОВІ СЛОВА: серце; щури; адреналін; кальцій; кверцетин; пероксидне окиснення ліпідів; морфологічні зміни.

ВСТУП. Інфраркт міокарда є динамічним процесом, що супроводжується переходом оборотних змін до необоротного ішемічного ушкодження і завершується заміною зменшеної частини міокарда фріброзним рубцем. Розвиток фріброзу є диссрункціональним [1]. Для нормального фуннкціонування тканин активуються моноцити/макрофраги, порушення фуункції яких лежить в основі механізму розвитку тромбозу коронарних артерій [2]. Ішемічний некроз та запалення зумовлюють порушення фрункції міокарда [3]. Кардіоміоцити гинуть шляхом некробіозу, а френотипічно транссоормовані фрібробластоподібні клітини активуються для ініціювання "репаративного" фріброзу. Структурну цілісність міокарда

() А. М. Мусієнко, О. В. Денефріль, 3. М. Небесна, С. Б. Крамap, 2018. забезпечує рубцева тканина, збільшується жорсткість тканин і зростає ризик виникнення аритмій. Активовані міофібробласти сприяють синтезу колагену I типу і фріброзу, що викликає патологічну реконструкцію міокарда [4]. Некроз кардіоміоцитів активує запальну реакцію, стимулює репаративні процеси і може сприяти збільшенню зони ушкодження. У дорослих мишей макрофраги можуть індукувати запалення при пригніченні регенерації [5]. Тобто може спостерігатися хвилеподібний перебіг розвитку ушкодження серця і періоди покращення переходять до більш виражених патологічних змін.

Враховуючи те, що основною патогенною ланкою є розвиток запалення, окисного та азотного вибуху, спазму коронарних судин, некрозу і фріброзу, для вивчення ефрективності кардіопро- 
текторної дії доцільним є використання кверцетину (Кв), який має антиоксидантні, антиспазматичні, протизапальні, антисклеротичні властивості [6].

Мета дослідження-визначити взаємозв'язок між змінами продуктів пероксидного окиснення ліпідів, окисної модифрікації білків (ОМБ), нітрит-аніона та морфологічними порушеннями в серці тварин з адреналіново-кальцієвою моделлю (АКМ) його ушкодження і при корекції патологічного процесу кверцетином.

МЕТОДИ ДОСЛІДЖЕННЯ. Досліди виконано на 195 щурах-самцях лінії Вістар віком 5-6 місяців. Тварин було поділено на групи: контроль, 1 год АКМ, 2 год АКМ, 24 год АКМ, 3 доби АКМ, 7 діб АКМ, 14 діб АКМ, 21 доба АКМ, 28 діб АКМ, Кв, 7 діб АКМ+Кв, 14 діб АКМ+Кв, 21 доба АКМ+Кв, 28 діб АКМ+Кв. Щурам вводили одноразово внутрішньом'язово 0,18 \% розчин адреналіну гідротартрату з розрахунку 0,5 мг/кг маси тварини (ПрАТ “Фармацевтична фрірма “Дарниця”, Україна) і внутрішньочеревно $5 \%$ розчин глюконату кальцію (“Дніпрофрарм", Україна) 3 розрахунку 1 мл/100 мл маси. Для корекції вводили інтраперитонеально розчин кверцетину 3 розрахунку 200 мг/кг маси. У тварин забирали серце для біохімічного аналізу та шматочки серця на рівні поперечного перерізу обох шлуночків для гістологічного дослідження. У гомогенаті серця визначали концентрацію дієнових кон'югатів (ДК) [7], ТБК-активних продуктів [8], ОМБ [9], нітрит-аніона [10]. Препарати вивчали при забарвленні гематоксиліном і еозином та за Гейденгайном. Також їх вивчали за допомогою світлового мікроскопа "MICROmed SEO SCAN" з поляризатором і аналізатором.

Усі експерименти проводили в першій половині дня в спеціально відведеному приміщенні при температурі $18-22^{\circ} \mathrm{C}$, відносній вологості 40-60 \% і освітленості 250 лк. Досліди виконано з дотриманням норм Європейської конвенції про захист хребетних тварин, що використовуються для дослідних та інших наукових цілей (Страсбург, 1986), ухвали Першого національного конгресу з біоетики (Київ, 2001) і наказу МО3 України від 23.09.2009 р. № 690.

Евтаназію щурів проводили шляхом тотального кровопускання із серця після попереднього тіопентал-натрієвого наркозу (60 мг·кг-1 маси тіла тварини внутрішньочеревно).

Статистичну обробку цифрових даних виконано за допомогою програмного забезпечення Excel ("Microsoft", США) i STATISTICA 6.0 ("Statsoft", США). Достовірність різниці значень між незалежними кількісними величинами визначали при нормальному розподілі за критерієм Стьюдента, в інших випадках - за допомогою непараметричних методів.

РЕЗУЛЬТАТИ Й ОБГОВОРЕННЯ. ЧереЗ 24 год після введення адреналіну і кальцію концентрація ДК зросла, порівняно з контрольними показниками, на 8,7 \% (p<0,02) (табл. 1).

Через 3 доби значення ДК збільшилися на $21,8$ \% ( $<<0,05)$ порівняно 3 контролем. Через 7 діб відмічено максимальні показники ДК, які були вищими відносно контролю в 4,6 раза $(p<0,001)$. Через 14 діб показники залишалися більшими від контрольних значень в 1,9 раза

Таблиця 1 - Зміни показників пероксидного окиснення ліпідів у серці тварин

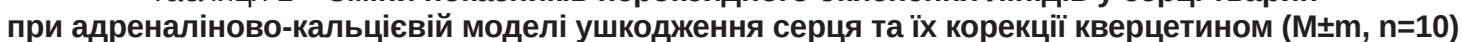

\begin{tabular}{|l|c|c|}
\hline \multirow{2}{*}{ Група } & \multicolumn{2}{|c|}{ Показник } \\
\cline { 2 - 3 } & ДК, ум. од. $\cdot \Gamma^{-1}$ & ТБК-акТивні продукти, мкмоль/кг \\
\hline Контроль & $1,002 \pm 0,013$ & $0,991 \pm 0,007$ \\
\hline 1 год АКМ & $1,011 \pm 0,020$ & $1,203 \pm 0,008^{*}$ \\
\hline 2 год АКМ & $1,012 \pm 0,008$ & $1,227 \pm 0,010^{*}$ \\
\hline 24 год АКМ & $1,090 \pm 0,031^{*, * *}$ & $1,373 \pm 0,008^{*}$ \\
\hline 3 доби АКМ & $1,221 \pm 0,097^{*}$ & $1,476 \pm 0,013^{*}$ \\
\hline 7 діб АКМ & $4,622 \pm 0,099^{*}$ & $1,511 \pm 0,013^{*}$ \\
\hline 14 діб АКМ & $1,913 \pm 0,027^{*}$ & $3,924 \pm 0,069^{*}$ \\
\hline 21 доба АКМ & $1,451 \pm 0,009^{*}$ & $2,163 \pm 0,049^{*}$ \\
\hline 28 діб АКМ & $1,006 \pm 0,021$ & $1,323 \pm 0,008^{*}$ \\
\hline Кв & $0,900 \pm 0,016^{*}$ & $0,211 \pm 0,034^{*}$ \\
\hline 7 діб АКМ+Кв & $1,088 \pm 0,012^{*, * * \&}$ & $1,221 \pm 0,009^{*, * *, \&}$ \\
\hline 14 діб АКМ+Кв & $0,906 \pm 0,012^{*, \&}$ & $2,214 \pm 0,027^{*, *, \&}$ \\
\hline 21 доба АКМ+Кв & $0,845 \pm 0,011^{* * *, \&}$ & $1,406 \pm 0,007^{*, * *, \&}$ \\
\hline 28 діб АКМ+Кв & $1,052 \pm 0,015^{*, * *}$ & $1,061 \pm 0,006^{*, *, \&}$ \\
\hline
\end{tabular}

Примітки. Тут і в таблиці 2:

1. * - показники достовірні порівняно з контролем.

2. ** - показники достовірні порівняно з кверцетином.

3. \& - показники достовірні порівняно з результатами без корекції. 
( $<<0,001)$. Через 21 добу результати виявилися вищими від контрольних цифр на 44,8 \% $(\mathrm{p}<0,001)$. Через 28 діб показники не відрізнялися від контрольних.

Введення кверцетину призвело до зменшення значень ДК, порівняно з контролем, на 10,2 \% $(p<0,001)$. Корекція патологічного процесу кверцетином зумовила значне зниження показників ДК: через 7 діб - на 76,4 \% ( $<<0,001)$, через 14 діб - на 52,6 \% ( $<<0,001)$, через 21 добу - на $41,7 \%$ ( $<<0,001)$ порівняно 3 тваринами, яким не проводили корекції, але через 28 діб значення достовірно не відрізнялися. Порівняно 3 контролем результати виявилися більшими через 7 діб (на 8,6 \%, р<0,001) і 28 діб (на 4,9\%, р<0,02) та меншими через 14 діб (на 9,6\%, p<0,001) і 21 добу (на 15,7\%, p<0,001). Через 21 добу значення були навіть нижчими на $6,1 \%$ $(p<0,02)$ порівняно з даними після введення кверцетину, а через 7 діб перевищували їх на $20,8 \%(p<0,001)$, через 28 діб - на 16,8 \% $(p<0,001)$.

Також відмічено зміни ТБК-активних продуктів. Через 1 год після введення адреналіну і кальцію спостерігали зростання, порівняно 3 контролем, значень ТБК-активних продуктів на $21,4 \%(p<0,001)$, через 2 год - на 23,8\% $(p<0,001)$, через 24 год - на $38,5 \%(p<0,001)$. Через 3 доби вони знову підвищувались на $49 \%$ $(p<0,001)$ порівняно з контролем. Через 7 діб показники збільшилися, порівняно з контрольними, на 52,5\% ( $<<0,001)$, через 14 діб - у 4 рази $(p<0,001)$. У цей термін вміст ТБК-активних продуктів був найвищим за весь час експерименту. Через 21 добу, порівняно з контролем, він був у 2,2 раза $(p<0,001)$ більшим. Через 28 діб значення ТБК-активних продуктів, порівняно з контролем, були вищими на 33,5 \% ( $<<0,001)$.

Введення кверцетину призвело до зменшення значень ТБК-активних продуктів, порівняно 3 контролем, на 78,7 \% ( $p<0,001)$. Корекція патологічного процесу кверцетином зумовила значне зниження показників ТБК-активних продуктів: через 7 діб - на 19,2 \% (p<0,001), через 14 діб на 43,6\% (p<0,001), через 21 добу - на $35 \%$ $(p<0,001)$, через 28 діб - на 19,8\% $(p<0,001)$ порівняно з тваринами без корекції. Порівняно 3 контролем результати виявилися вищими в усі терміни дослідження: через 7 діб - на 23,2 \% $(p<0,001)$, через 14 діб - у 2,2 раза $(p<0,001)$, через 21 добу - на 41,9\% $(p<0,001)$, через 28 діб - на $7 \%(p<0,001)$. Порівняно з кверцетином показники були більшими в усі терміни: через 7 діб - у 5,8 раза ( $p<0,001)$, через 14 діб у 10,5 раза ( $p<0,001)$, через 21 добу - в 6,7 раза $(p<0,001)$, через 28 діб - у 5 разів $(p<0,001)$.

Отже, досліджувана комбінація препаратів призвела до значної активації продуктів пероксидного окиснення ліпідів 3 максимумом їх накопичення через 7 і 14 діб з моменту введення. Кверцетин щодо отриманих показників мав протекторний вплив, який був значно вираженим до 21 доби.

При дослідженні показників ОМБ (табл. 2) виявлено підвищення концентрації ОМБ ${ }_{370}$ порівняно з контролем: через 1 год - на $28 \%$ $(p<0,001)$, через 2 год - на 32,6\% $(p<0,001)$. Значення різко зросли через 24 год і були більшими в 3,3 раза $(\mathrm{p}<0,001)$ порівняно 3 контролем. Через 3 доби показники перевищували контроль у 15,9 раза $(p<0,001)$. Через 7 діб концентрація OMБ $_{370}$ почала знижуватися, але була більшою, порівняно 3 контролем, у 6,1 раза $(p<0,001)$. Через 14 діб вона ще перевищувала контрольні значення на 78,6 \% $(p<0,001)$. Через 21 та 28 діб показники не відрізнялися від контролю.

Введення кверцетину спричинило зменшення ОМБ порівняно 3 контролем: ОМБ $48,9 \%(p<0,001)$, OMБ $_{430}-$ на 63,5 \% $(p<0,001)$. Введення адреналіну і кальцію при корекції ним

Таблиця 2 - Зміни продуктів окисної модифікації білків і нітрит-аніона у тварин при розвитку

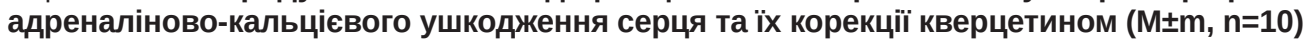

\begin{tabular}{|c|c|c|c|}
\hline \multirow{2}{*}{ Група } & \multicolumn{3}{|c|}{ Показник } \\
\hline & ОМБ $_{370,}$ ммоль/г білка & ОМБ $_{430}$, ммоль/г білка & Нітрит-аніон, ×10-3, мкмоль/кг \\
\hline Контроль & $681,97 \pm 13,21$ & $549,52 \pm 36,01$ & $0,884 \pm 0,019$ \\
\hline 1 год АКМ & $881,61 \pm 28,90 *$ & $720,56 \pm 18,30^{*}$ & $1,667 \pm 0,029^{*}$ \\
\hline 2 год АКМ & $903,26 \pm 8,74^{*}$ & $881,61 \pm 28,90^{*}$ & $1,769 \pm 0,025^{*}$ \\
\hline 24 год АКМ & $3049,59 \pm 30,33^{*}$ & $903,26 \pm 8,74^{*}$ & $2,164 \pm 0,028^{*}$ \\
\hline З доби АКМ & $11072,25 \pm 375,40^{*}$ & $9583,87 \pm 94,65^{*}$ & $2,452 \pm 0,043^{*}$ \\
\hline 7 діб АКМ & $4194,62 \pm 212,99^{*}$ & $4241,08 \pm 161,21^{*}$ & $2,151 \pm 0,042^{*}$ \\
\hline 14 діб АКМ & $1218,10 \pm 18,18^{*}$ & $1365,52 \pm 6,17^{\star}$ & $2,425 \pm 0,116^{*}$ \\
\hline 21 доба АКМ & $661,03 \pm 6,33$ & $452,34 \pm 11,15^{*}$ & $1,742 \pm 0,056^{*}$ \\
\hline 28 діб АКМ & $680,56 \pm 8,01$ & $524,16 \pm 3,16$ & $1,769 \pm 0,027^{*}$ \\
\hline KB & $348,23 \pm 1,40^{*}$ & $200,65 \pm 1,27^{\star}$ & $0,757 \pm 0,047^{\star}$ \\
\hline 7 діб АКМ+Кв & $1061,55 \pm 10,92^{*, * *, \&}$ & $720,56 \pm 18,30^{*, * *, \&}$ & $1,876 \pm 0,033^{*, * *, \&}$ \\
\hline 14 діб АКМ+Кв & $864,20 \pm 2,22^{*, * *, \&}$ & $1358,59 \pm 12,56^{*, * *}$ & $1,715 \pm 0,050^{*, * *, \&}$ \\
\hline 21 доба АКМ+Кв & $1070,05 \pm 1,13^{*, * *, \&}$ & $1040,92 \pm 10,03^{*, * *, \&}$ & $1,273 \pm 0,053^{*, * *, \&}$ \\
\hline 28 діб АКМ+Кв & $555,34 \pm 11,53^{*, * *, \&}$ & $370,75 \pm 2,68^{*, * *, \&}$ & $1,219 \pm 0,025^{*, *, \&}$ \\
\hline
\end{tabular}


патологічного процесу викликало протекторний вплив: через 7 діб показники ОМБ ${ }_{370}$ знизилися на 74,7\% ( $<<0,001)$, через 14 діб - на $29 \%$ ( $<<0,001)$, через 21 добу вони зросли на 61,9\% ( $p<0,001)$, а через 28 діб спостерігали значне їх зменшення - на 18,4 \% ( $<<0,001)$. Порівняно 3 контролем результати були вищими: через 7 діб - на 54,7 \% (p<0,001), через 14 діб - на 26,7\% (p<0,001), через 21 добу - на 56,9 \% $(\mathrm{p}<0,001)$, а через 28 діб, навпаки, виявились нижчими на 18,6 \% (p<0,001). Порівняно з введенням одного кверцетину протягом 7 днів значення були більшими в усі терміни дослідження: через 7 діб - у 3 рази ( $p<0,001)$, через 14 діб - у $2,5$ раза ( $<<0,001)$, через 21 добу - в 3,1 раза ( $p<0,001)$, через 28 діб - на 59,4 \% ( $<<0,001)$.

Показники ОМБ ${ }_{430}$ почали достовірно зростати вже через 1 год від початку експерименту - на $30,1 \%$ ( $<0,001)$, через 2 год вони збільшилися, порівняно 3 контролем, на 58,9 \% (p<0,001), через 24 год були вищими від контрольних показників на 64,5% (p<0,001). Через 3 доби різко збільшилися, порівняно з контролем, у 17,4 раза $(p<0,001)$, досягаючи максимальних значень. У подальшому значно знижувалися, але були вищими від контролю: через 7 діб - у 7,6 раза $(p<0,001)$, через 14 діб - у 2,5 раза $(p<0,001)$. Через 21 добу значення були навіть меншими від контрольних цифрр на 17,7 \% ( $p<0,05)$, а через 28 діб не відрізнялися від них.

Розвиток АКМ при корекції патологічного процесу спричинив протекторний вплив через 7 діб: показники ОМБ ${ }_{430}$ різко знизилися на $82,8 \%$ ( $<<0,001)$, через 21 добу зросли у 2,3 раза $(p<0,001)$, а через 28 діб значно зменшились - на 29,3 \% (p<0,001). Порівняно з контролем результати були вищими: через 7 діб - на 30,1 \% $(\mathrm{p}<0,001)$, через 14 діб - у 2,5 раза $(\mathrm{p}<0,001)$, через 21 добу - на 89,4 \% (p<0,001), а через 28 діб, навпаки, нижчими - на 32,5 \% (p<0,001). Через 14 діб значення були більшими, ніж у попередній термін дослідження, на 90,1 \% ( $<<0,001)$, через 21 добу - меншими на 23,4 \% $(p<0,001)$, через 28 діб значно знизилися - на $64,3$ \% ( $<<0,001)$. Порівняно 3 кверцетином показники були вищими в усі терміни дослідження: через 7 діб - у 3,6 раза ( $p<0,001)$, через 14 діб у 6,8 раза ( $\mathrm{p}<0,001)$, через 21 добу - в 5,2 раза ( $p<0,001)$, через 28 діб - на 84,8 \% ( $<<0,001)$.

Отже, введення адреналіну і кальцію тваринам спричинило значну активацію ОМБ з максимальним ефектом через 3 доби. Через 21 і 28 діб впливу на ОМБ не відмічено. Кверцетин мав протекторний ефект через 7, 14 і 28 діб з моменту розвитку патологічного процесу.

При дослідженні нітрит-аніона виявлено швидше його накопичення вже через 1 год - на
$88,6 \%$ ( $<<0,001)$, через 2 год значення збільшилися, порівняно з контролем, у 2 рази ( $<<0,001)$, через 24 год відбулося наступне накопичення нітрит-аніона порівняно з контролем - у 2,4 раза $(p<0,001)$. Через 3 доби показники перевищували контроль у 2,8 раза ( $<<0,001)$. Максимальні значення спостерігали через 3 і 14 діб: порівняно 3 контролем вони були більшими у 2,8 раза $(\mathrm{p}<0,001)$ та 2,7 раза $(\mathrm{p}<0,001)$, через 7 діб - у $2,4$ раза ( $<<0,001)$. Через 21 і 28 діб показники перевищували контрольні на 97 \% (p<0,001) й у 2 рази $(p<0,001)$.

Введення кверцетину спричинило менше накопичення нітрит-аніона порівняно з контролем - на 14,4 \% (p<0,05). Введення адреналіну і кальцію при корекції кверцетином викликало протекторний вплив через 7 діб: показники нітрит-аніона знизилися на 12,8\% ( $<<0,001)$, через 14 діб - на 29,3 \% ( $<<0,001)$, через 21 добу - на $26,9 \%$ ( $<<0,001)$, а через 28 діб - на 31,1 \% $(p<0,001)$. Порівняно 3 контролем результати були вищими в усі терміни дослідження: через 7 діб - у 2,1 раза ( $<<0,001)$, через 14 діб - на 93,9 \% ( $p<0,001)$, через 21 добу - на 43,9\% $(p<0,001)$, а через 28 діб - на 37,9 \% ( $<<0,001)$. Порівняно з кверцетином показники були більшими в усі терміни дослідження: через 7 діб -у 2,5 раза $(\mathrm{p}<0,001)$, через 14 діб - у 2,3 раза $(p<0,001)$, через 21 добу - на 68,1\% ( $<<0,001)$, через 28 діб - на 61,1 \% (p<0,001).

Таким чином, у тварин розвинувся нітрооксидативний стрес із максимальним його розвитком через 3 доби, який у всі терміни дослідження добре корегувався кверцетином.

Отримані біохімічні зміни відповідали морфологічним. Через 1 год виявлено вогнищеві деструктивні ураження м'язових волокон, порушення їх тинкторіальних властивостей, вогнища лейкоцитарної інорільтрації, відмічено стази і кровонаповнення судин, зросла кількість некротизованих клітин, які були розташовані як поодиноко, так і мали зливний характер. Через 2 год на фроні попередньо виявлених змін відзначено вихід еритроцитів із судинного русла, збільшення площі ділянок із некротизованими кардіоміоцитами. Через 24 год посилювалися морфологічні зміни, навколо кровонаповнених судин подекуди спостерігали ділянки просвітлення, вогнища некрозів займали по 5-6 кардіоміоцитів. Через 3 доби відмічено розшарування тканини міокарда, збільшення зони просвітлення навколо судин, зростання ділянок некрозу. В судинах йшла організація тромбів, вони ставали неоднорідними. Через 7 діб виявлені зміни посилювалися. Через 14 діб навколо судин спостерігали ділянки сполучної тканини. Через 21 добу на фроні змін, що відбувались у попередні термі- 
ни дослідження, відмічено вихід еритроцитів у навколишню тканину. Через 28 діб сполучна тканина навколо судин ущільнювалася, в міокарді виявляли еритроцити (рис. 1).

Після введення Кв відмічено менше ураження серця, через 21 і 28 діб не спостерігали виходу еритроцитів у міокард (рис. 2). Кількість некро-

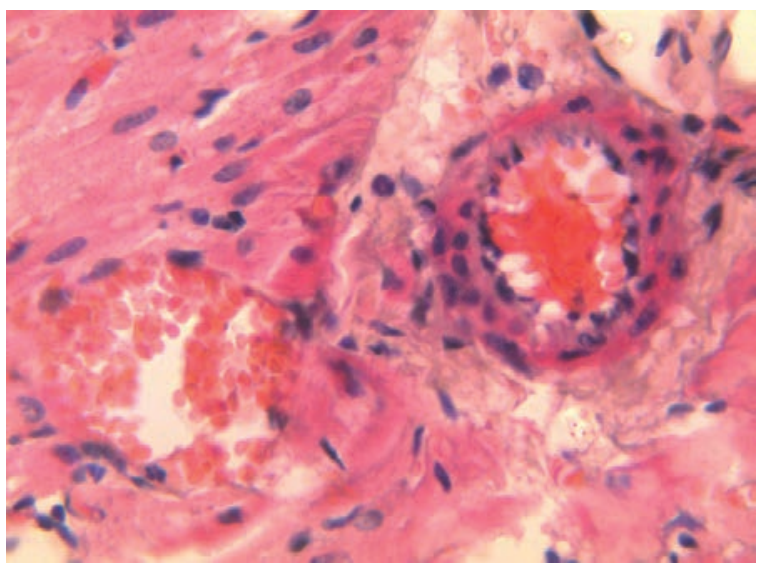

Рис. 1. Гістологічні зміни міокарда щура через 28 діб досліду. Забарвлення гематоксиліном і еозином. ×200.

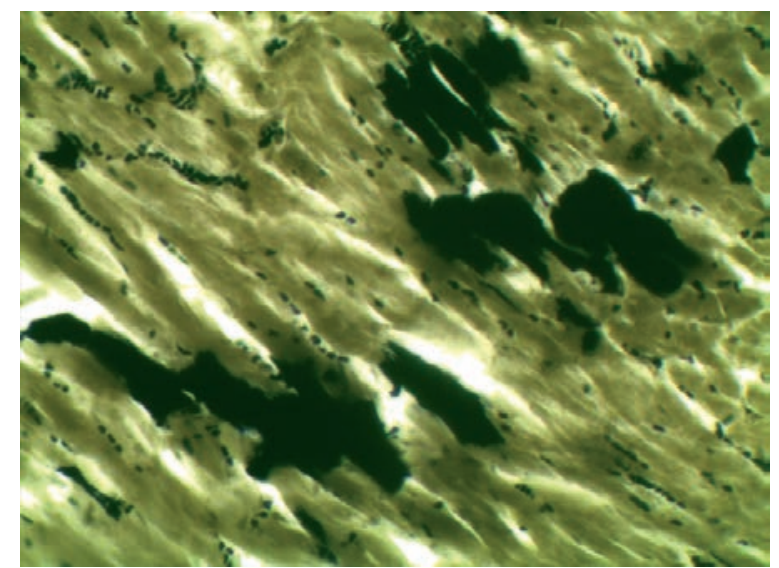

Рис. 3. Гістологічні зміни міокарда щура через 7 діб досліду. Забарвлення за Гейденгайном. ×200.

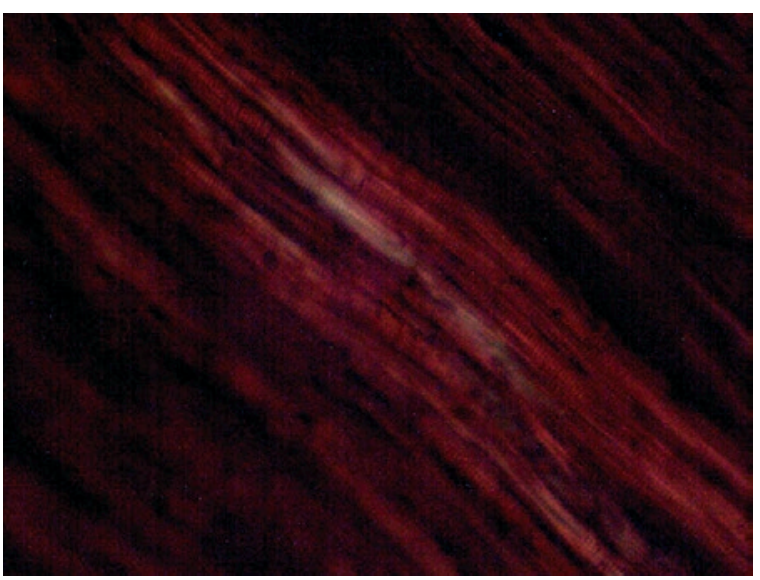

Рис. 5. Гістологічні зміни міокарда щура через 14 діб досліду. Вогнищева анізотропія кардіоміоцитів. Поляризаційна мікроскопія. $\times 200$. тизованих клітин у тварин, які отримували препарат для корекції, була значно меншою (рис. 3, 4).

При розгляді препаратів у поляризованому світлі виявлено наростання ступеня анізотропії, контрактурних змін із збільшенням терміну дослідження. Кверцетин зменшував прояви патологічних змін (рис. 5, 6).

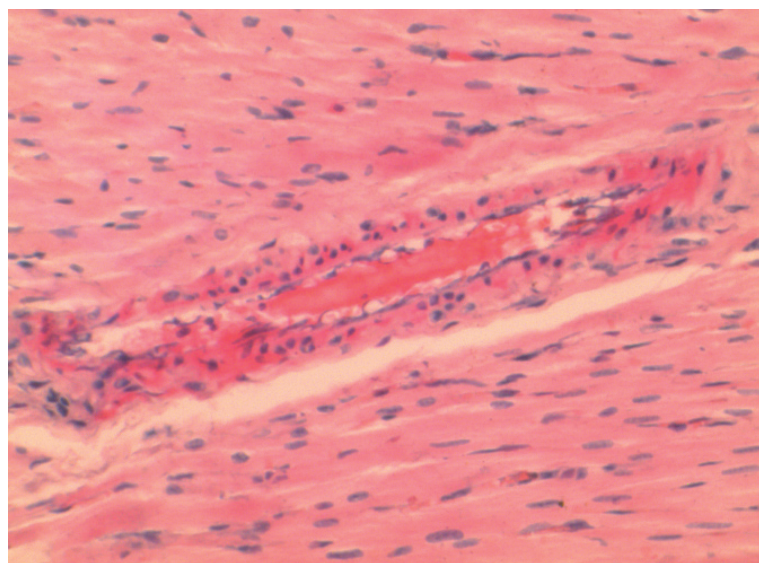

Рис. 2. Гістологічні зміни міокарда щура через 28 діб досліду при корекції кверцетином. Забарвлення гематоксиліном і еозином. $\times 200$.

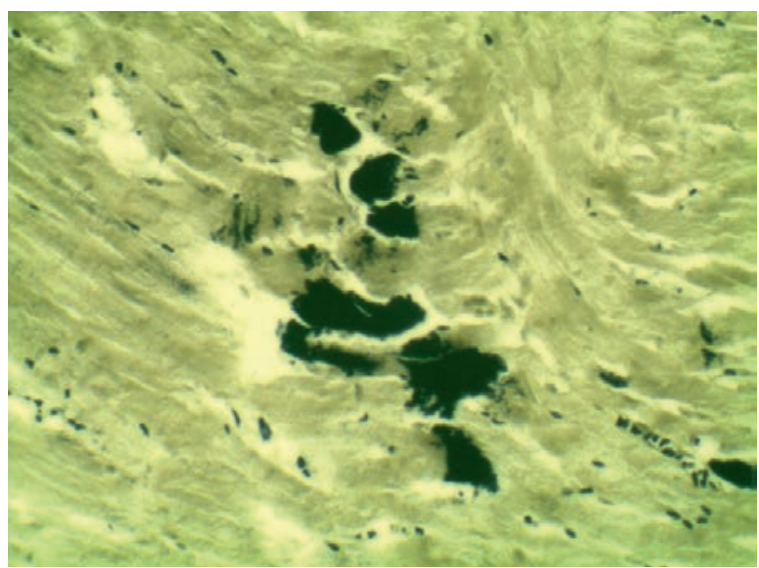

Рис. 4. Гістологічні зміни міокарда щура через 14 діб досліду. Забарвлення за Гейденгайном. ×200.

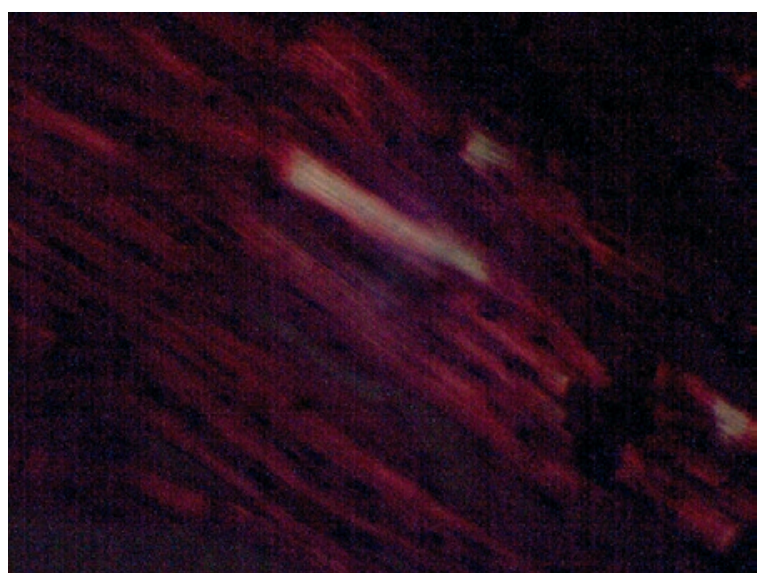

Рис. 6. Гістологічний зріз міокарда щура через 21 добу досліду. Вогнищева анізотропія та цитоліз кардіоміоцитів. Поляризаційна мікроскопія. ×200. 
ВИСНОВКИ. 1. Виявлені морфологічні зміни підтверджували дані біохімічних показників. Найбільше зростання продуктів пероксидного окиснення ліпідів спостерігали через 7 і 14 діб, продуктів ОМБ - через 24 год, через 3 доби (максимум), через 7 діб. Концентрація нітританіона була високою в проміжку від 24 год до 21 доби (через 3 і 14 діб відмічено максимуми). Кверцетин сприяв зменшенню вмісту продуктів ОМБ через 7, 14 і 28 діб, ДК - через 7, 14 і 21 доби, ТБК-активних продуктів, нітрит-аніона в усі терміни дослідження.

2. Адреналіново-кальцієва модель ушкодження серця спричинила значні порушення структури міокарда: порушення тинкторіальних властивостей, виникнення некрозів, контрактур. Зміни наростали зі збільшенням терміну дослідження та поєднувалися з відхиленнями біохімічних показників. Кверцетин попереджував виникнення ушкоджень.

Перспективи подальших досліджень. Для вияснення механізмів кардіопротекторної дії буде досліджено вплив препаратів, які направлені на нормалізацію гемостазу й ендотеліальної диссрункції, на пізніх етапах адреналіново-кальцієвої моделі.

\section{СПИСОК ЛІТЕРАТУРИ}

1. Segura A. M. Fibrosis and heart failure / A. M. Segura, O. H. Frazier, L. M. Buja // Heart Fail. Rev. -2014. 19 (2). - P. 173-185. doi: 10.1007/s10741-012-9365-4.

2. Monocytes/macrophages prevent healing defects and left ventricular thrombus formation after myocardial infarction / S. Frantz, U. Hofmann, D. Fraccarollo [et al.] // FASEB J. - 2013. - 27 (3). - P. 871-881. doi: 10.1096/ fj.12-214049.

3. Hashmi S. Acute myocardial infarction and myocardial ischemia-reperfusion injury: a comparison / S. Hashmi, S. Al-Salam // Int. J. Clin. Exp. Pathol. 2015. - 8 (8). - P. 8786-8796.

4. Myofibroblast-mediated mechanisms of pathological remodelling of the heart / K. T. Weber, Y. Sun, S. K. Bhattacharya [et al.] // Nat. Rev. Cardiol. - 2013. 10 (1). - P. 15-26. doi: 10.1038/nrcardio. 2012.158.

5. Frangogiannis N. G. Inflammation in cardiac injury, repair and regeneration / N. G. Frangogiannis // Curr. Opin. Cardiol. - 2015. - 30 (3). - P. 240-245. doi: 0.1097/ HCO.0000000000000158.

\section{REFERENCES}

1. Segura, A.M., Frazier, O.H., \& Buja, L.M. Fibrosis and heart failure. Heart Fail Rev., 19 (2), 173-185. doi: 10.1007/s10741-012-9365-4.

2. Frantz, S., Hofmann, U., Fraccarollo, D., Schäfer, A., Kranepuhl, S., Hagedorn, I., Nieswandt, B. et al. (2013). Monocytes/macrophages prevent healing defects and
6. Шеремета Л. Противиразкова дія ліпосомального кверцетину при субхронічній виразці шлунка в експерименті / Л. Шеремета // Вісн. СумДУ. Серія "Медицина". - 2008. - № 1. - С. 43-47.

7. Хышиктуев Б. С. Методы определения продуктов перекисного окисления липидов в конденсате выдыхаемого воздуха и их клиническое значение / Б. С. Хышиктуев, Н. А. Хышиктуева, В. Н. Иванов // Клин. лаб. диагностика. - 1996. - № 3. - С. 13-15.

8. Доклінічні дослідження лікарських засобів : метод. рек. / за ред. О. В. Стефранова. - К. : Авіцена, 2001. - С. 528.

9. Арчаков А. И. Модисрикация белков активным кислородом и их распад / А. И. Арчаков, И. М. Мохосаев // Биохимия. - 1998. - 54, № 2. - С. 179-186.

10. Analisis of nitrate, nitrite and $[15 N]$ nitrate in biological fluids / I. C. Green, A. W. Davie, J. Golawski [et al.] // Anal. Biochem. - 1982. - 126 (1). - P. 131-138. left ventricular thrombus formation after myocardial infarction. FASEB J. 2013; 27 (3), 871-881. doi: 10.1096/fj.12214049.

3. Hashmi, S., \&Al-Salam, S. (2015). Acute myocardial infarction and myocardial ischemia-reperfusion injury: a comparison. Int. J. Clin. Exp. Pathol., 8 (8), 87868796. 
4. Weber, K.T., Sun, Y., Bhattacharya, S.K., Ahokas, R.A., \& Gerling, I.C. (2013). Myofibroblast-mediated mechanisms of pathological remodelling of the heart. Nat. Rev. Cardiol., 10 (1), 15-26. doi: 10.1038/nrcardio. 2012.158.

5. Frangogiannis, N.G. (2015). Inflammation in cardiac injury, repair and regeneration. Curr. Opin. Cardiol., 30 (3), 240-245. doi: 0.1097/HCO.0000000000000158.

6. Sheremeta, L. (2008). Protyvyrazkova diia liposomalnoho kvertsetynu pry subkhronichnii vyraztsi shlunka $v$ eksperymenti [Antiulcerous activity of liposomal quercetin at experimental subacute gastric ulcer]. Visnyk SumDU. Seriia Medytsyna - Herald of Sumy State University. The series Medicine, 1, 43-47 [in Ukrainian].

7. Khyshiktuyev, B.S., Khyshiktuyeva, N.A., \& Ivanov, V.N. (1996). Metody opredeleniya produktov perekisnogo okisleniya lipidov v kondensate vydykhayemogo vozdukha i ikh klinicheskoye znachenie [Methods of determination of products of lipids peroxidation in exhaled air condensate and their clinical significance]. Klinicheskaya laboratornaya diagnostika - Clinical Laboratory Diagnostics, 3, 13-15 [in Russian].

8. Stefanov, O.V. (Ed.). Doklinichni doslidzhennia likarskykh zasobiv: metodychni rekomendatsii [Preclinical research of medicinal products: methodical recommendations]. Kyiv: Avitsenna [in Ukrainian].

9. Archakov, A.I., \& Mokhosoyev, I.M. (1998). Modifikatsiya belkov akivnym kislorodom i ikh raspad [Modification of proteins by active oxygen and their decomposition]. Biokhimiya - Biochemistry, 54 (2), 179-185 [in Russian].

10. Green, I.C., Davie, A.W., \& Golawski, J. (1982). Analysis of nitrate, nitrite and $[15 \mathrm{~N}]$ nitrate in biological fluids. Anal. Biochem., 126 (1), 131-138.

А. М. Мусиенко, О. В. Денефиль, 3. М. Небесная, С. Б. Крамар ТЕРНОПОЛЬСКИЙ ГОСУДАРСТВЕННЫЙ МЕДИЦИНСКИЙ УНИВЕРСИТЕТ ИМЕНИ И. Я. ГОРБАЧЕВСКОГО

\section{БИОХИМИЧЕСКИЕ МАРКЕРЫ МОРФОЛОГИЧЕСКИХ ИЗМЕНЕНИЙ В МИОКАРДЕ КРЫС ПРИ ЕГО АДРЕНАЛИНОВО-КАЛЬЦИЕВОМ ПОВРЕЖДЕНИИ}

\section{Резюме}

Вступление. Инфаркт миокарда является динамическим процессом, который сопровождается переходом обратимых изменений к необратимому ишемическому повреждению и завершается заменой уменьшеной части миокарда фриброзным рубцом.

Цель исследования - определить взаимосвязь между изменениями продуктов перекисного окисления липидов, окислительной модификации белков (ОМБ), нитрит-аниона и морфрологическими нарушениями в сердце животных с адреналиново-кальциевой моделью его повреждения и при коррекции патологического процесса кверцетином.

Методы исследования. Опыты выполнены на 195 крысах-самцах линии Вистар в возрасте 5-6 месяцев. Животным вводили адреналина гидротартрат и глюконат кальция, для коррекции - кверцетин. В сердце определяли концентрацию диеновых конъюгатов, ТБК-активных продуктов, ОМБ, нитританиона. Гистологические препараты изучали при окрашивании гематоксилином и эозином, по Гейденгайну, а также рассматривали их в поляризованном свете.

Результаты и обсуждение. При адреналиново-кальциевой модели повреждения сердца наибольшее возрастание концентрации диеновых конъюгатов и ТБК-активных продуктов наблюдали через 7 и 14 суток, ОМБ - через 24 ч, через 3 суток (максимум), через 7 суток. Концентрация нитрит-аниона была высокой в промежутке от 24 ч до 21 суток (через 3 и 14 суток отмечены максимумы). Кверцетин способствовал уменьшению содержания продуктов ОМБ через 7, 14 и 28 суток, диеновых конъюгатов - через 7, 14 и 21 сутки, ТБК-активных продуктов, нитрит-аниона - во все сроки исследования. При морорологическом исследовании выявлено нарушение тинкториальных свойств, возникновение некрозов, контрактур. Изменения нарастали с увеличением срока исследования и отвечали по времени отклонениям биохимических показателей. Кверцетин предупреждал возникновение повреждений.

Выводы. Выявленные морфологические изменения подтверждали данные биохимических показателей. Морфологические изменения нарастали с увеличением срока исследования и соответствовали отклонениям биохимических показателей. Кверцетин уменьшал возникновение повреждений в сердце.

КЛЮЧЕВЫЕ СЛОВА: сердце; крысы; адреналин; кальций; кверцетин; перекисное окисление липидов; морфологические изменения. 


\section{BIOCHEMICAL MARKERS OF MORPHOLOGICAL CHANGES IN MYOCARDIUM OF RATS IN ITS ADRENALIN-CALCIUM DAMAGE}

\section{Summary}

Introduction. Myocardial infarction is a dynamic process accompanied by the transition of reversible changes to irreversible ischemic injury and completes the replacement of the reduced part of the myocardium by a fibrous scar

The aim of the study - to determine the relationship between changes in lipid peroxidation products, oxidative modification of proteins (OMP), nitrite anion and morphological disorders in the heart of animals with adrenalincalcium model (ACM) of its lesion and correction of the pathological process by quercetin (Que).

Research Methods. Experiments were performed on 195 Wistar male rats, 5-6 months old. Rats were injected with adrenaline hydrotartrate and calcium gluconate, for correction - quercetin. In the heart, diene conjugates (DC), TBA-active products, OMP, nitrite anion were determined. Histologic preparations were studied by staining with hematoxylin and eosin, by Heidgenheim, and they were also seen in polarized light.

Results and Discussion. At ACM, cardiac involvement in the growth of DC and TBA-active products was greatest after 7 days and 14 days, OMP - after 24 hours, 3 days (maximum), 7 days. The concentration of nitrite anion was high from 24 hours to 21 days (after 3 days and 14 days, the peaks were noted). Quercetin contributed to reducing the content of OMP after 7, 14 and 28 days, DC - 7, 14 and 21 days, TBA-active products, nitrite anion in all terms of the study. In the morphological study revealed a violation of tincter properties, the appearance of necrosis, contracture. Changes grew with an increase in the duration of the research and corresponded to deviations of biochemical indicators. Quercetin prevents the onset of lesions.

Conclusions. The revealed morphological changes confirmed the data of biochemical parameters. Morphological changes grew with an increase in the duration of the study and corresponded to the deviation of biochemical parameters. Quercetin reduced the lesion.

KEY WORDS: heart; rats; adrenalin; calcium; quercetin; lipid peroxidation; morphological changes.

Адреса для листування: О. В. Денефріль, Тернопільський державний медичний університет імені І. Я. Горбачевського, майдан Волі, 1, Тернопіль, 46001, Україна, e-mail: denefil@tdmu.edu.uа. 